\title{
Evaluation of Efficacy and Compatibility of Herbicides with Fungicides in Durum Wheat (Triticum durum Desf.) under Different Environmental Conditions: Effects on Grain Yield and Gluten Content
}

\author{
Anestis KARKANIS*, Evangelos VELLIOS, Filippos GRIGORIOU, \\ Theodoros GKRIMPIZIS, Persephoni GIANNOULI
}

\author{
University of Thessaly, Department of Agriculture Crop Production and Rural Environment, Fytokou St., 38446, Volos, \\ Greece; anekark80@yahoo.gr (*orrespondingauthor); evellios@uth.gr; figrigor@hotmail.gr;gribizis@hotmail.com; pergian@uth.gr
}

\begin{abstract}
In the present study, field experiments were conducted to determine the efficacy and compatibility of herbicides and fungicides in durum wheat under Mediterranean semi-arid conditions, in Central Greece. Our results indicate that the herbicide florasulam+2.4-D was safe and did not cause any injury when applied alone or with fungicides, while bromoxynil+2.4-D mixed with azoxystrobin or trifloxystrobin+prothioconazole caused injury symptoms on leaves. The injury symptoms were transient, and observed only at Velestino area, where low temperatures and broad diurnal temperature fluctuations were recorded during the pesticides application period. Regarding septoria leaf blotch control, good results showed strobilurin alone or in mixture with a triazole, regardless the herbicide that was added to the mixture. The results of this study showed that bromoxynil+2.4-D caused injury when mixed with fungicides and applied under cold temperatures, while one fungicide application at stem elongation provided adequate Septoria leaf blotch control.
\end{abstract}

Keywords: flour quality; incompatibility; Papaver rhoeas; pesticides; Sinapis arvensis

\section{Introduction}

Durum wheat (Triticum durum Desf.) and common wheat (Triticum aestivum L.) are two of the most important field crops cultivated around the world. The cultivated area was about 220 million hectares in 2014 (FAO, 2014). In the last 35 years, a decrease of $7 \%$ in the cultivated area was registered, while the production was increased around 30\% despite the reduction of cultivated land. This increase is mainly due to the development of high yielding varieties and improved cultural practices.

Weeds remain a major constraint to wheat production despite the use of herbicides (Karkanis et al., 2016). The magnitude of yield losses, mainly depends on crop density, nitrogen fertilization, time of weed emergence, weed species and density (Dhima and Eleftherohorinos, 2001; Fahad et al., 2015; Karkanis et al., 2016). For instance, Qasem (2007) observed that wild oat (Avena sterilis L.) control, increased wheat yields up to $20 \%$, while in another study Dhima and Eleftherohorinos (2001) reported that wheat yield losses due to wild oat competition was $61 \%$. Other important factors that influence wheat growth and production are foliar diseases such as Puccinia graminis f. sp. tritici (wheat stem rust, Terefe et al., 2016), Puccinia striiformis f.sp. tritici (yellow rust, Holtz et al., 2014) and Mycosphaerella graminicola (Septoria leaf blotch, Castro and Simón, 2016). Severe infections by these pathogens can cause significant yield losses, while foliar sprays with fungicides are necessary. In a recent study, conducted in the United States by Lopez et al. (2015) found that one protective application of the fungicide tebuconazole caused a yield gain up to $9 \%$. In recent years, severe infections by $M$. graminicola caused high yield losses in Greece, and fungicide applications are generally needed to control this disease.

Due to the high cost of wheat production, it is crucial to minimize the application cost of pesticides. Reduction of the total cost can be achieved with combined application of fungicide and herbicide (Robinson et al., 2013). However, when choosing to tank-mix herbicides and fungicides, the cereal farmers should be aware of the incompatibility of pesticides mixtures. Physical incompatibility may occur when two or more pesticides are mixed in the same tank. This type of incompatibility refers to either phase separation or the mixture may curdle or transform to a gel (Sarwar, 2015).

In some instances, the pesticides activity is influenced when two or more pesticides are mixed. Additive, potentiated, synergistic or antagonism effect can occur as 
602

the result of pesticides combination. However, among them, antagonism is a type of incompatibility of great importance to agriculture that results in the reduction of pesticides efficacy. For example, Lancaster et al. (2008) reported that pyraclostrobin reduced herbicide efficacy against Urochloa platyphylla (Munro ex C. Wright) R.D. Webster. Furthermore, pesticides combinations can cause phytotoxicity on plants. Robinson et al. (2013) found that some herbicides mixed with tebuconazole caused injury on wheat.

Cautions or instructions regarding the compatibility of pesticides are included on some pesticides labels, while others include the direction that all mixtures should be tested prior to mixing commercial quantities. Thus, the main objective of the current study was to evaluate the compatibility of herbicides and fungicides on durum wheat (Triticum durum Desf.) under different environmental conditions. Data on weed control ratings, wheat visible injury, disease severity, crop yield and quality were recorded.

\section{Materials and Methods}

\section{Study site}

The experiment was repeated twice. Durum wheat (Triticum durum cv. 'Quandrato') was established at two sites: a) at the experimental field of the University of Thessaly in Velestino, Thessaly region $(22.756 \mathrm{E}, 39.396 \mathrm{~N}$; Site 1). The soil was sandy clay loam (38\% sand, $36 \%$ silt, and $26 \%$ clay), with $\mathrm{pH} 7.4\left(1: 1\right.$ soil $\left./ \mathrm{H}_{2} \mathrm{O}\right)$, and b) at Domokos region in Central Greece $(22.336 \mathrm{E}, 39.036 \mathrm{~N}$; Site 2). The soil of this site was clay ( $50.7 \%$ clay, $23.3 \%$ silt, and $26 \%$ sand) with $\mathrm{pH} 7.6\left(1: 1\right.$ soil $\left./ \mathrm{H}_{2} \mathrm{O}\right)$. Wheat was
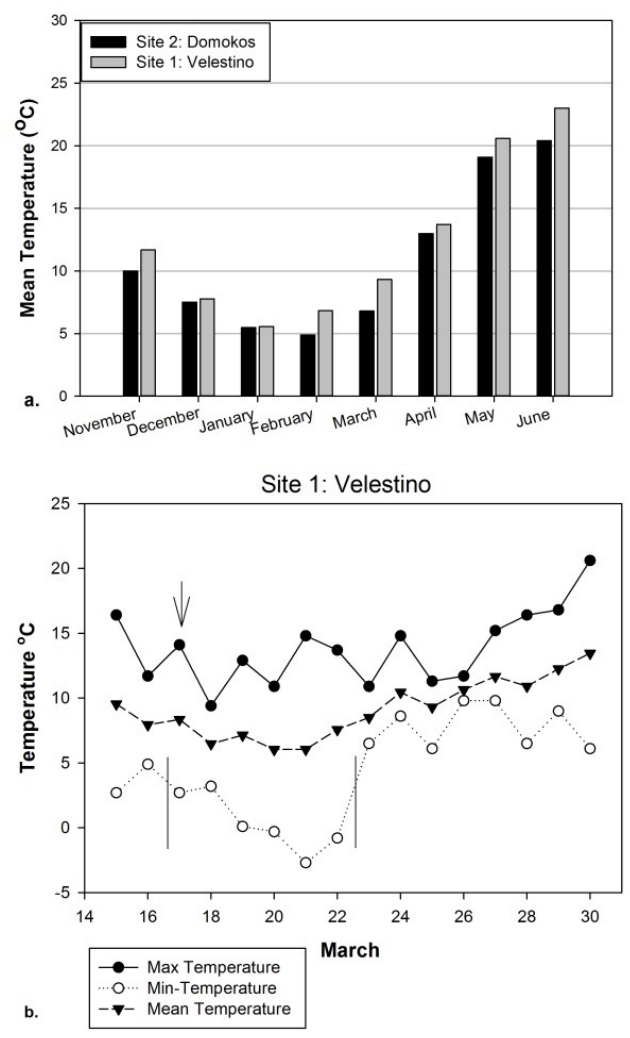

sown on the $17^{\text {th }}$ of November 2014 and $8^{\text {th }}$ of November 2014, at Velestino and Domokos, respectively. Meteorological data of both sites are presented in Fig. 1.

\section{Experimental design}

The experimental design was a randomized complete block design with four replicates per treatment for both sites. The treatments were as follows: untreated control, bromoxynil+2.4-D, florasulam+2.4-D, bromoxynil+2.4-D /azoxystrobin, bromoxynil+2.4-D /trifloxystrobin +prothioconazole, florasulam+ 2.4-D/azoxystrobin, florasulam+2.4-D/trifloxystrobin+prothioconazole. These herbicides and fungicides are widely used in cereals in Greece and were applied at recommended doses (bromoxynil+2.4-D: $420+420$ g a.i. ha $^{-1}$, florasulam+2.4-D: $5+240 \mathrm{~g}$ a.i. ha $\mathrm{ha}^{-1}$ azoxystrobin: $250 \mathrm{~g}$ a.i. $\mathrm{ha}^{-1}$, trifloxystrobin+prothioconazole: $100.32+199.50 \mathrm{~g}^{2}$ a.i. $\mathrm{ha}^{-1}$. The experimental field was set up over an area of $630 \mathrm{~m}^{2}$, with plots of $2.25 \mathrm{~m}$ wide and $6.5 \mathrm{~m}$ long. Wheat was sown in rows $18 \mathrm{~cm}$ apart at a depth of $3 \mathrm{~cm}$, at a rate of $250 \mathrm{~kg}$ $\mathrm{ha}^{-1}$. The pesticides were applied with a handheld field plot sprayer with constant pressure of $250 \mathrm{kPa}$, using a total water volume of $300 \mathrm{~L} \mathrm{ha}^{-1}$ and flat-fan nozzles. The pesticides were applied at first node (Zadoks growth stage 31) on 17 March 2015 and 4 April 2015, at Velestino and Domokos, respectively.

\section{Sampling and measurements}

For the measurements of height, tillers and ear length, 10 plants were randomly selected in each plot. To define biomass (dry weight) the plants were cut at $1 \mathrm{~m}^{2}$ in each plot. Then, plant samples $(2 \mathrm{~kg}$ ) were dried for $96 \mathrm{~h}$ at $60{ }^{\circ} \mathrm{C}$. For the determination of grain yield, plots were
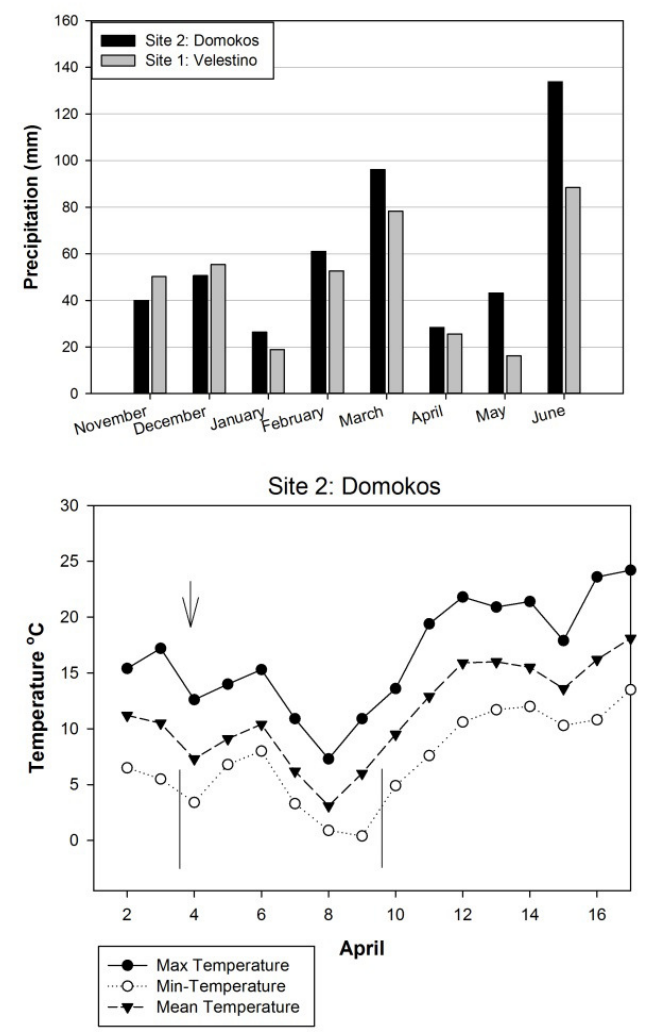

Fig. 1. a) Meteorological data for the experimental sites during the growing period (November 2014-June 2015), and b) Daily high, mean and low temperature at each site during the day of pesticides application and for the following 2 weeks. The arrows shows the pesticides application time 
harvested on 22 June 2015 and 2 July 2015, at site 1 and 2, respectively. After harvest, 1000-grain weight was calculated by randomly weight 400 grains from each treatment. Chlorophyll content was measured in the field (SPAD value), using the portable SPAD-502 chlorophyll meter (Konica Minolta, Optics, Inc., Osaka, Japan). SPAD measurements were made at ten flag leaves in each plot. Moreover, wet gluten content (WGC) was measured according to a method described in ISO 21415-1 (2006).

In order to assess the number of the dominant weeds a wooden square quadrate $(0.40 \times 0.40 \mathrm{~m})$ was placed at random twice in each plot, while for determination of the disease severity, 15 flag leaves were randomly selected in each plot. The selected leaves were scanned with a $600 \mathrm{dpi}$ resolution and disease severity was determined using WinFOLIA Pro software (Regent Instruments Inc., Canada). Regarding the leaf injury due to combination of fungicides with herbicides, 14 days after application the injury was assessed visually and expressed as \% percentage of the injured leaves to the total number of leaves examined.

\section{Statistical analysis}

The data were subjected to statistical analysis according to the randomized complete block design. Analysis of variance was conducted for all data and differences between means were separated using Fisher's Least Significant Difference (LSD) test at $P<0.05$. Pearson's correlation analysis was used to describe the relationships between wheat growth parameters and disease severity. The statistical analysis was performed with SigmaPlot 12 software (Systat Software Inc., San Jose, CA).

\section{Results}

\section{Herbicide-fungicide compatibility and efficacy}

At Velestino, the main weeds were Anthemis arvensis L. (corn chamomile) and Sinapis arvensis L. (wild mustard), while at Domokos the main weeds were $S$. arvensis and Papaver rhoeas L. (corn poppy). A comparison of the performance of the herbicides on $S$. arvensis and $A$. arvensis revealed similar susceptibility of these weed species to bromoxynil+2.4-D and florasulam+2.4-D (Table 1). Regardless the experimental site, herbicides efficacy were not affected when applied with azoxystrobin or trifloxystrobin+prothioconazole. Furthermore, at Domokos no injury symptoms were obvious after pesticides application. At the Velestino site, florasulam+2.4-D alone or in combination with fungicides did not cause any injury, while bromoxynil+2.4-D mixed with azoxystrobin or trifloxystrobin+prothioconazole caused necrotic spots on wheat leaves. The highest level of injury was $5.18 \%$ with the application of bromoxynil+2.4-D in combination with trifloxystrobin+prothioconazole (Table 2). The observed symptoms were transient and plants recovered soon.

Regarding the $M$. graminicola severity, there were significant differences between treatments. At both sites, the highest disease severity was recorded in untreated control (10.7 and 33.5\%, at Velestino and Domokos respectively) and in plots treated with herbicides, while the lowest values were observed in herbicides-fungicides mixtures. At the Domokos site, the lowest disease severity was found in plots treated with trifloxystrobin+prothioconazole. It's worth

Table 1. Control of Anthemis arvensis, Sinapis arvensis and Papaver rhoeas by various herbicide treatments at two experimental sites

\begin{tabular}{|c|c|c|c|c|}
\hline \multirow{3}{*}{ Treatments } & \multicolumn{4}{|c|}{ Herbicides efficacy $(\%)$} \\
\hline & \multicolumn{2}{|c|}{ Site 1:Velestino } & \multicolumn{2}{|c|}{ Site 2: Domokos } \\
\hline & Sinapis arvensis & Anthemis arvensis & Sinapis arvensis & Papaver rhoeas \\
\hline bromoxynil+2.4-D & $100 \mathrm{a}$ & $93.3 \mathrm{a}$ & $100 \mathrm{a}$ & $87.5 \mathrm{a}$ \\
\hline bromoxynil+2.4-D/ azoxystrobin & $100 \mathrm{a}$ & $95.2 \mathrm{a}$ & $99.5 \mathrm{a}$ & $90.7 \mathrm{a}$ \\
\hline bromoxynil+2.4-D/trifloxystrobin+prothioconazole & $98 \mathrm{a}$ & $93.9 \mathrm{a}$ & $100 \mathrm{a}$ & $89.4 a$ \\
\hline florasulam+2.4-D & $99 \mathrm{a}$ & $91.8 \mathrm{a}$ & $97.2 \mathrm{a}$ & $90.8 \mathrm{a}$ \\
\hline florasulam+2.4-D/azoxystrobin & $100 \mathrm{a}$ & $95.1 \mathrm{a}$ & $100 \mathrm{a}$ & $87.6 \mathrm{a}$ \\
\hline florasulam+2.4-D/trifloxystrobin+prothioconazole & $98.8 \mathrm{a}$ & $94.8 \mathrm{a}$ & $99.1 \mathrm{a}$ & $92.3 \mathrm{a}$ \\
\hline Fvalues & $0.648^{\text {ns }}$ & $0.184^{\mathrm{ns}}$ & $0.898^{\text {ns }}$ & $0.400^{\mathrm{ns}}$ \\
\hline
\end{tabular}

Table 2. Effects of herbicides and herbicides/fungicides mixtures on relative chlorophyll content (SPAD values), disease severity on flag leaves (\%) and visible injury (\%) of wheat crop at two experimental sites

\begin{tabular}{|c|c|c|c|c|c|c|}
\hline \multirow[b]{2}{*}{ Treatments } & \multicolumn{2}{|c|}{ SPAD values } & \multicolumn{2}{|c|}{ Disease severity (\%) } & \multicolumn{2}{|c|}{ Injury (\%) } \\
\hline & $\begin{array}{l}\text { Site 1: } \\
\text { Velestino }\end{array}$ & $\begin{array}{c}\text { Site 2: } \\
\text { Domokos }\end{array}$ & $\begin{array}{l}\text { Site 1: } \\
\text { Velestino }\end{array}$ & $\begin{array}{l}\text { Site 2: } \\
\text { Domokos }\end{array}$ & $\begin{array}{c}\text { Site 1: } \\
\text { Velestino }\end{array}$ & $\begin{array}{c}\text { Site 2: } \\
\text { Domokos }\end{array}$ \\
\hline untreated control & $31.83 \mathrm{c}$ & $29.30 \mathrm{~d}$ & $10.70 \mathrm{a}$ & $33.50 \mathrm{a}$ & $0 \mathrm{c}$ & 0 \\
\hline bromoxynil+2.4-D & $36.78 b$ & $34.95 \mathrm{c}$ & $8.03 \mathrm{a}$ & $31.49 \mathrm{a}$ & $0 \mathrm{c}$ & 0 \\
\hline bromoxynil+2.4-D/azoxystrobin & $41.81 \mathrm{a}$ & $40.13 b$ & $2.09 \mathrm{~b}$ & $13.29 b$ & $1.98 \mathrm{~b}$ & 0 \\
\hline $\begin{array}{l}\text { bromoxynil+2.4-D/ } \\
\text { trifloxystrobin+prothioconazole }\end{array}$ & $42.85 \mathrm{a}$ & $43.78 \mathrm{a}$ & $2.83 \mathrm{~b}$ & $4.76 \mathrm{~b}$ & $5.18 \mathrm{a}$ & 0 \\
\hline florasulam+2.4-D & $38.30 \mathrm{~b}$ & $35.01 \mathrm{c}$ & $8.49 \mathrm{a}$ & $35.35 \mathrm{a}$ & $0 \mathrm{c}$ & 0 \\
\hline florasulam+2.4-D/azoxystrobin & $41.60 \mathrm{a}$ & $39.80 \mathrm{~b}$ & $3.47 b$ & $11.03 b$ & $0 \mathrm{c}$ & 0 \\
\hline $\begin{array}{l}\text { florasulam+2.4-D/ } \\
\text { trifloxystrobin+prothioconazole }\end{array}$ & $42.25 a$ & $43.06 \mathrm{a}$ & $2.36 \mathrm{~b}$ & $3.87 \mathrm{~b}$ & $0 \mathrm{c}$ & 0 \\
\hline $\mathrm{LSD}_{5 \%}$ & 2.021 & 1.126 & 3.048 & 11.82 & 0.874 & - \\
\hline F values & $34.639^{* * *}$ & $186.60^{* * *}$ & $11.871^{* * *}$ & $12.232^{* * *}$ & $45.025^{* * *}$ & - \\
\hline
\end{tabular}


604

noting that the first symptoms of the disease were recorded in December and February, at Domokos and Velestino, respectively.

\section{Cropparameters}

Regardless the experimental site, all the herbicidefungicide mixtures affected the SPAD values of flag leaves (Table 2). The highest SPAD values were observed in bromoxynil $+2.4-\mathrm{D} /$ trifloxystrobin+prothioconazole and florasulam $+2.4-\mathrm{D} /$ trifloxystrobin+prothioconazole treatments, while the lowest were recorded in untreated control (29.30 and 31.83, at Domokos and Velestino, respectively.

The herbicide-fungicide mixtures did not affect the plant height (Table 3). At both sites, the lowest height was recorded in untreated control $(94.1$ and $86.9 \mathrm{~cm}$, at Velestino and Domokos, respectively). Moreover, at Domokos location, the lowest number of tillers were found in untreated control, while all the herbicide treatments had positive effect on tillers number. Concerning the dry biomass, there were significant differences between treatments. The lowest dry biomass was observed in untreated control (7625 and $7197 \mathrm{~kg} \mathrm{ha}^{-1}$, at Velestino and Domokos, respectively). At both sites, all the herbicidefungicide treatments resulted in greater dry biomass than bromoxynil+2.4-D or florasulam+2.4-D treatments. Regarding the yield components, the herbicide-fungicide mixtures did not affect ear length (Table 4). At both sites, the lowest ear length was recorded in untreated control (5.8 and $5.53 \mathrm{~cm}$, at Velestino and Domokos, respectively), while at Velestino location, all the herbicide-fungicide treatments resulted in greater 1000-grain weight than that in bromoxynil+2.4-D or florasulam+2.4-D treatments.

Regarding the grain yield, there were significant differences between the treatments at both sites. The lowest grain yield was observed in untreated control (2703 and $2150 \mathrm{~kg} \mathrm{ha}^{-1}$, at Velestino and Domokos, respectively). At Velestino, all the herbicide-fungicide treatments resulted in greater grain yield than bromoxynil+2.4-D or florasulam+2.4-D treatments, while there were no differences between herbicide-fungicide combinations. In contrast, at Domokos, there were yield differences between herbicide-fungicide mixtures. Concerning the wet gluten content, at Velestino, bromoxynil+2.4-D/azoxystrobin, bromoxynil $+2.4-\mathrm{D} /$ trifloxystrobin+prothioconazole, florasulam+2.4-D/azoxystrobin and florasulam+2.4-D/ trifloxystrobin+prothioconazole treatments resulted in greater wet gluten content. On the contrary, in Domokos, there were no differences between treatments in wet gluten content which ranged from 20.36 to $26.10 \%$. Comparing the two sites the lowest wet gluten content was determined in wheat samples from Domokos region.

\section{Discussion}

\section{Herbicide-fungicide compatibility}

Although combination of pesticides is a common practice worldwide, very few studies have been published examining the compatibility of these substances. Florasulam +2.4-D alone or in combination with fungicides did not cause any injury since florasulam is rapidly metabolized by wheat (half-life $=2.4 \mathrm{~h}$ ), as reported by DeBoer $e$ al. (2006), while bromoxynil+2.4-D mixed with azoxystrobin or trifloxystrobin+prothioconazole caused injury on wheat leaves only at Velestino area. In earlier studies, Robinson et al. (2013) also observed that bromoxynil+MCPA in combination with tebuconazole or azoxystrobin+propiconazole resulted in injury on wheat leaves, while Chahal and Johnson (2012) reported that glufosinate caused injury in soybean when combined with pyraclostrobin (fungicide) or lambda-cyhalothrin (insecticide).

Wheat injury by bromoxynil+2.4-D/fungicides mixtures may be the result of environmental conditions during the application period. At site 1, temperatures below zero and broad diurnal fluctuations of temperatures were recorded within 2 to 5 days after application (Fig. 1b). It is possible that the injury was a result of these climate conditions. In the contrary, Robinson et al. (2013) reported that cold temperatures during application did not enhance injury of wheat when certain mixtures of herbicidesfungicides were applied, but fungicides or their components may enhance the uptake of herbicides which caused the crop injury. Some herbicides labels also restrict application on crops under stress due to widely fluctuating temperatures

Table 3. Effects of herbicides and herbicides/fungicides mixtures on height $(\mathrm{cm})$, tiller number (no plant $\left.{ }^{-1}\right)$ and dry biomass $\left(\mathrm{kg} \mathrm{ha}^{-1}\right)$ of wheat crop at two experimental sites

\begin{tabular}{|c|c|c|c|c|c|c|}
\hline \multirow[b]{2}{*}{ Treatments } & \multicolumn{2}{|c|}{ Height $(\mathrm{cm})$} & \multicolumn{2}{|c|}{ Tillers number $\left(\right.$ no plant $\left.^{-1}\right)$} & \multicolumn{2}{|c|}{ Dry biomass $\left(\mathrm{kg} \mathrm{ha}^{-1}\right)$} \\
\hline & $\begin{array}{c}\text { Site 1: } \\
\text { Velestino }\end{array}$ & $\begin{array}{c}\text { Site 2: } \\
\text { Domokos }\end{array}$ & $\begin{array}{c}\text { Site 1: } \\
\text { Velestino }\end{array}$ & $\begin{array}{c}\text { Site 2: } \\
\text { Domokos }\end{array}$ & $\begin{array}{c}\text { Site 1: } \\
\text { Velestino }\end{array}$ & $\begin{array}{c}\text { Site 2: } \\
\text { Domokos }\end{array}$ \\
\hline untreated control & $94.10 \mathrm{~b}$ & $86.9 \mathrm{c}$ & $2.50 \mathrm{a}$ & $2.44 b$ & $7625 c$ & $7197 \mathrm{c}$ \\
\hline bromoxynil+2.4-D & $108.2 \mathrm{a}$ & $91.8 b$ & $2.67 \mathrm{a}$ & $2.83 \mathrm{a}$ & $8487 b$ & $7837 b$ \\
\hline bromoxynil+2.4-D/azoxystrobin & $106.3 \mathrm{a}$ & $96.9 \mathrm{a}$ & $2.42 \mathrm{a}$ & $2.98 \mathrm{a}$ & $9232 \mathrm{a}$ & $8995 a$ \\
\hline $\begin{array}{l}\text { bromoxynil+2.4-D/ } \\
\text { trifloxystrobin+prothioconazole }\end{array}$ & $101.8 \mathrm{a}$ & $95.5 \mathrm{a}$ & $2.50 \mathrm{a}$ & $2.88 \mathrm{a}$ & $9372 \mathrm{a}$ & $9052 \mathrm{a}$ \\
\hline florasulam+2.4-D & $106.8 \mathrm{a}$ & $92.2 b$ & $2.58 \mathrm{a}$ & $2.93 \mathrm{a}$ & $8560 \mathrm{~b}$ & $7792 b$ \\
\hline florasulam+2.4-D/azoxystrobin & $104 a$ & $96.5 \mathrm{a}$ & $2.33 \mathrm{a}$ & $2.85 \mathrm{a}$ & $9147 \mathrm{a}$ & $8935 a$ \\
\hline $\begin{array}{l}\text { florasulam+2.4-D/ } \\
\text { trifloxystrobin/prothioconazole }\end{array}$ & $105.1 \mathrm{a}$ & $97.5 \mathrm{a}$ & $2.42 \mathrm{a}$ & $2.80 \mathrm{a}$ & $9295 \mathrm{a}$ & $9002 \mathrm{a}$ \\
\hline $\mathrm{LSD}_{5 \%}$ & 7.42 & 2.19 & - & 0.219 & 252.98 & 206.07 \\
\hline F values & $3.583^{*}$ & $27.01^{* * *}$ & $0.896^{\text {ns }}$ & $5.710^{* *}$ & $55.508^{* * *}$ & $123.36^{* * *}$ \\
\hline
\end{tabular}

Notes: Means in the same column followed by different letters are significantly different according to Fisher's Least Significant Difference (LSD) test $(\mathrm{P}<0.05) .{ }^{*}{ }^{* *}$ and ${ }^{* * *}$ significant at $\mathrm{P}<0.05, \mathrm{P}<0.01$ and $\mathrm{P}<0.001$, respectively. ns $=$ no significant. 
Table 4. Effects of herbicides and herbicides/fungicides mixtures on ear length $(\mathrm{cm}), 1000$-grain weight $(\mathrm{g})$, wet gluten content (\%) and grain yield $\left(\mathrm{kg} \mathrm{ha}^{-1}\right)$ of wheat crop at two experimental sites

\begin{tabular}{|c|c|c|c|c|c|c|c|c|}
\hline \multirow[b]{2}{*}{ Treatments } & \multicolumn{2}{|c|}{ 1000-grain weight $(\mathrm{g})$} & \multicolumn{2}{|c|}{ Ear length $(\mathrm{cm})$} & \multicolumn{2}{|c|}{ Grain yield $\left(\mathrm{kg} \mathrm{ha}^{-1}\right)$} & \multicolumn{2}{|c|}{ Wet gluten content (\%) } \\
\hline & $\begin{array}{c}\text { Site 1: } \\
\text { Velestino }\end{array}$ & $\begin{array}{c}\text { Site 2: } \\
\text { Domokos }\end{array}$ & $\begin{array}{l}\text { Site 1: } \\
\text { Velestino }\end{array}$ & $\begin{array}{c}\text { Site 2: } \\
\text { Domokos }\end{array}$ & $\begin{array}{l}\text { Site 1: } \\
\text { Velestino }\end{array}$ & $\begin{array}{c}\text { Site 2: } \\
\text { Domokos }\end{array}$ & $\begin{array}{l}\text { Site 1: } \\
\text { Velestino }\end{array}$ & $\begin{array}{c}\text { Site 2: } \\
\text { Domokos }\end{array}$ \\
\hline untreated control & $43.38 \mathrm{c}$ & $44.13 \mathrm{c}$ & $5.80 \mathrm{~b}$ & $5.53 \mathrm{~b}$ & $2703 c$ & $2150 \mathrm{~d}$ & $27.45 \mathrm{~b}$ & $20.36 \mathrm{a}$ \\
\hline bromoxynil+2.4-D & $45.78 \mathrm{~b}$ & $45.48 \mathrm{~b}$ & $6.45 a$ & $6.10 \mathrm{a}$ & $3598 b$ & $3050 \mathrm{c}$ & $30.60 \mathrm{ab}$ & $21.30 \mathrm{a}$ \\
\hline bromoxynil+2.4-D/azoxystrobin & $47.13 \mathrm{a}$ & $46.02 \mathrm{~b}$ & $6.33 a$ & $6.20 \mathrm{a}$ & $4225 a$ & $3338 \mathrm{~b}$ & $33.60 \mathrm{ab}$ & $24.45 \mathrm{a}$ \\
\hline $\begin{array}{c}\text { bromoxynil+2.4-D/ } \\
\text { trifloxystrobin+ } \\
\text { prothioconazole }\end{array}$ & $47.50 \mathrm{a}$ & $47.63 \mathrm{a}$ & $6.40 \mathrm{a}$ & $6.05 a$ & $4348 a$ & $3883 a$ & $37.05 a$ & $24.75 \mathrm{a}$ \\
\hline florasulam+2.4-D & $45.38 b$ & $46.00 \mathrm{~b}$ & $6.28 \mathrm{a}$ & $5.90 \mathrm{a}$ & $3468 \mathrm{~b}$ & $3108 b c$ & $30.00 \mathrm{ab}$ & $25.20 \mathrm{a}$ \\
\hline $\begin{array}{c}\text { florasulam+2.4-D/ } \\
\text { azoxystrobin }\end{array}$ & $48.08 \mathrm{a}$ & $45.63 \mathrm{~b}$ & $6.45 a$ & $6.05 a$ & $4265 a$ & $3268 b c$ & $36.10 \mathrm{a}$ & $26.10 \mathrm{a}$ \\
\hline $\begin{array}{l}\text { florasulam+2.4-D/ } \\
\text { trifloxystrobin+prothioconazole }\end{array}$ & $47.30 \mathrm{a}$ & $48.03 \mathrm{a}$ & $6.38 \mathrm{a}$ & $6.15 \mathrm{a}$ & $4493 a$ & $3770 a$ & $39.30 \mathrm{a}$ & $24.60 \mathrm{a}$ \\
\hline $\mathrm{LSD}_{5 \%}$ & 1.29 & 0.96 & 0.310 & 0.302 & 357.50 & 257.84 & 7.344 & - \\
\hline Fvalues & $14.091^{* * *}$ & $16.71^{* * *}$ & $4.77^{* *}$ & $5.065^{* *}$ & $28.742^{* * *}$ & $43.01^{* * *}$ & $3.098^{*}$ & $1.097^{\mathrm{ns}}$ \\
\hline
\end{tabular}

Notes: Means in the same column followed by different letters are significantly different according to Fisher's Least Significant Difference (LSD) test $(\mathrm{P}<0.05) .^{* * *}{ }^{* * *}$ significant at $\mathrm{P}<0.05, \mathrm{P}<0.01$ and $\mathrm{P}<0.001$, respectively. ns= no significant.

as crop injury may result, while according to Martini et al. (2015) the metabolism of herbicides is affected by cold temperatures. Summarizing, wheat injury by bromoxynil+2.4-D/fungicides mixtures, observed at site 1 , may be the result of a combination of the above factors (low temperatures and wide diurnal fluctuation of temperatures).

\section{Herbicides efficacy}

A comparison of the performance of herbicides on $S$. arvensis and $A$. arvensis revealed similar susceptibility of these weed species to bromoxynil+2.4-D and florasulam+2.4-D. Regardless the experimental site, herbicides efficacy were not affected when applied with azoxystrobin or trifloxystrobin+prothioconazole. Jordan $e t$ al. (2009) also found that the co-application of the fungicides azoxystrobin, pyraclostrobin, and tebuconazole with the herbicide imazapic did not affect Cyperus esculentus L. (yellow nutsedge) control. In the contrary, Lancaster et al. (2007) observed that chlorothalonil and pyraclostrobin reduced the efficacy of diclosulam against Ambrosia artemisiifolia L. (common ragweed) in peanut crop.

\section{Cropparameters}

Relative chlorophyll content (SPAD values) of flag leaf was measured as the flag leaf has a major impact on cereals yield. Thus, protecting this leaf is of major importance in order to achieve high yields (Gooding et al., 2000). In the present study, regardless the experimental site, all the herbicide-fungicide mixtures affected the SPAD values of flag leaves, while the disease severity had negative and significant correlation with SPAD values $(\mathrm{r}=-0.764$, $P<0.001$ and $\mathrm{r}=-0.798, P<0.001$, at Velestino and Domokos, respectively, Table 5). Our experiments also showed that a mixture of a triazole with a strobilurin gave better $M$. graminicola control in the region with high disease pressure. Similarly, Ishikawa et al. (2012) found greater severity of $M$. graminicola disease in plots treated with a triazole fungicide alone than those treated with a mixture of a triazole and a strobilurin. From disease assessments, it was also apparent that the lowest disease severity was found at Velestino. This could be attributed to differences in environmental conditions. The precipitation was greater in Domokos region than in Velestino, while average monthly temperature during the period of MarchMay were constantly higher at the Velestino site than at Domokos (Fig. 1a). Moreover, our results show that one fungicide application at stem elongation reduced significantly the disease severity. In a recent study, Gomes et al. (2016) reported that two fungicide applications at stem elongation (GS 34) and at booting (GS 47) provided better septoria leaf blotch and yellow rust control on susceptible wheat varieties, while no differences were observed between one application and two applications on moderate resistant or resistant wheat varieties. In the contrary, under different environmental conditions, Wiersma and Motteberg (2005) reported that the fungicide application at GS 60 (beginning of anthesis) provided better control of leaf diseases in wheat than that at GS 39 (flag leaf ligule/collar just visible). Thus, the choice of optimum time of fungicide applications for each region is critical to obtain high diseases control in wheat and it also depends on wheat varieties susceptibility to $M$. graminicola.

Concerning the dry biomass, there were significant differences between treatments, while the herbicidefungicide mixtures did not affect the plant height. Furthermore, the dry biomass had negative and significant correlation with disease severity $(\mathrm{r}=-0.830, P<0.001$ and $\mathrm{r}=-$ $0.797, P<0.001$, at Velestino and Domokos, respectively). Septoria leaf blotch also resulted in 1000-grain weight reduction, while all the herbicide-fungicide treatments resulted in greater 1000-grain weight than that in bromoxynil+2.4-D or florasulam $+2.4-\mathrm{D}$ treatments. In a recent study, Ishikawa et al. (2012) recorded that Septoria leaf blotch caused significant reduction in grain weight. These researchers also found negative relationship between the area under the disease progress curve (AUDPC) and mean grain weight.

The injury caused by bromoxynil+2.4-D/fungicide mixtures had no negative effect on durum wheat yield and quality, while a positive correlation was found between grain yield and SPAD values of flag leaves. The relationship 
606

was slightly stronger at Domokos than at Velestino (Fig. 2). Similarly, Robinson et al. (2013) found that the herbicidefungicide mixtures caused injury in wheat crop which did not reduce the wheat yield, whereas the application of herbicide-fungicide mixtures at Zadoks growth stage 37-39 resulted in greater grain yield and 1000 -grain weight than that in untreated control.

Comparing the two sites, the lowest wet gluten content was determined in wheat samples from Domokos region.
The main reason for lower flour quality at this site may be attributed to high level of rainfall during the grain ripening. In the last 2 weeks before harvest about $116 \mathrm{~mm}$ of precipitation and nine rainy days were recorded. Similarly, according to Gut and Bichoński (2007) and Uchimura et al. (2004) rainfall during the grain development and ripening period reduced the wheat quality.

Table 5. Pearson correlation coefficients between wheat growth parameters, disease severity and wet gluten content at site 1 and 2

\begin{tabular}{|c|c|c|c|c|c|c|c|}
\hline Site 1: Velestino & $\overline{\mathrm{DB}}$ & GW & $\overline{E L}$ & GY & WGC & SPAD & DS \\
\hline Dry biomass (DB) & - & $0.868^{* * *}$ & $0.663^{* * *}$ & $0.937^{* * *}$ & $0.574^{* *}$ & $0.950^{* * *}$ & $-0.830^{* * *}$ \\
\hline 1000-grain weight (GW) & & - & $0.585^{* *}$ & $0.827^{* * *}$ & $0.555^{* *}$ & $0.891^{* * *}$ & $-0.695^{* * *}$ \\
\hline Ear length (EL) & & & - & $0.634^{* * *}$ & $\mathrm{~ns}$ & $0.586^{* *}$ & ns \\
\hline Grain yield (GY) & & & & - & $0.499^{* *}$ & $0.875^{* * *}$ & $-0,832^{* * *}$ \\
\hline Wet gluten content (WGC) & & & & & - & $0.593^{* * *}$ & $-0.570^{* *}$ \\
\hline SPAD values (SPAD) & & & & & & - & $-0.764^{* * *}$ \\
\hline Disease severity (DS) & & & & & & & - \\
\hline Site 2: Domokos & DB & GW & EL & GY & WGC & SPAD & DS \\
\hline Dry biomass (DB) & - & $0.695^{* * *}$ & $0.585^{* * *}$ & $0.847^{* * *}$ & ns & $0.944^{* * *}$ & $-0.797^{* * *}$ \\
\hline 1000-grain weight (GW) & & - & $0.405^{*}$ & $0.833^{* * *}$ & ns & $0.816^{* * *}$ & $-0.631^{* * *}$ \\
\hline Ear length (EL) & & & - & $0.587^{* *}$ & ns & $0.615^{* * *}$ & ns \\
\hline Grain yield (GY) & & & & - & ns & $0.933^{* * *}$ & $-0.714^{* * *}$ \\
\hline Wet gluten content (WGC) & & & & & - & ns & ns \\
\hline SPAD values $(\mathrm{SPAD})$ & & & & & & - & $-0.798^{* * *}$ \\
\hline Disease severity (DS) & & & & & & & - \\
\hline
\end{tabular}

Site 1: Velestino

Grain yield $=140.873^{*}$ SPAD-1671.516 $\mathrm{r}=0.875, \mathrm{n}=28$

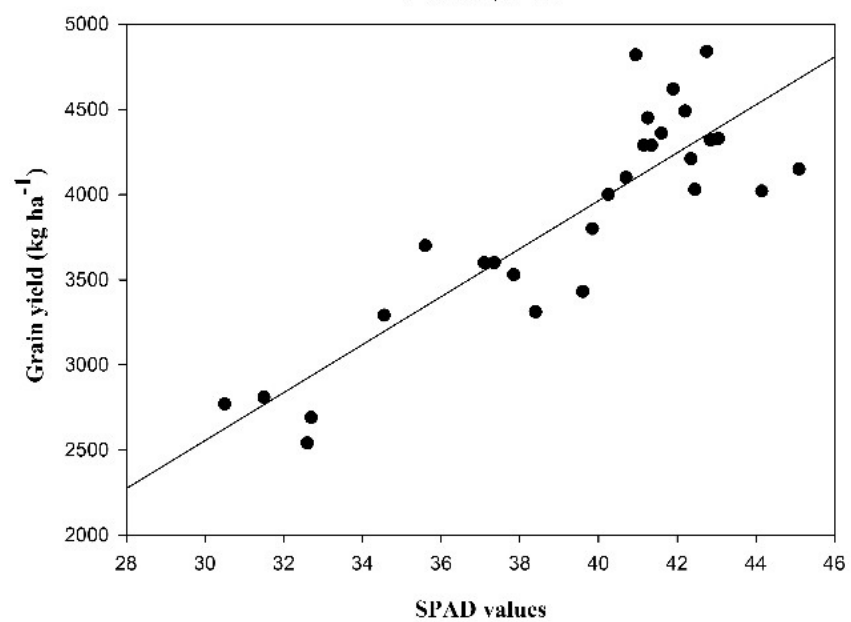

Site 2: Domokos Grain yicld $=105.302 * \mathrm{SP} \Lambda \mathrm{D}-779.260$ $\mathrm{r}=0.933^{* * *}, \mathrm{n}=28$

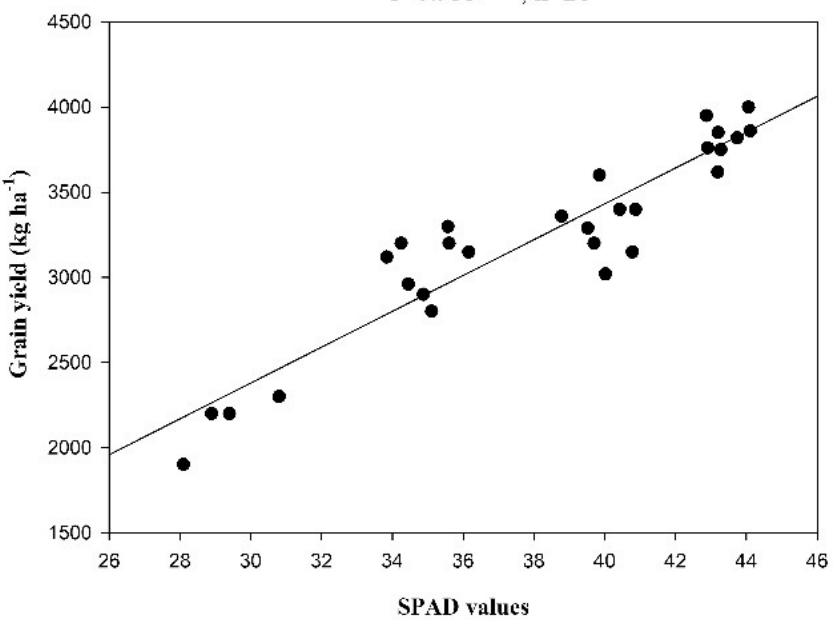

Fig. 2. Linear correlation between grain yield and SPAD values of wheat flag leaves at site 1 and 2

\section{Acknowledgements}

The authors would like to thank Spyridon Souipas and Christos Karamoutis for their technical assistance.

\section{References}

Castro AC, Simón MR (2016). Effect of tolerance to Septoria tritici blotch on grain yield, yield components and grain quality in Argentinean wheat cultivars. Crop Protection 90:66-76.

Chahal GS, Johnson WG (2012). Influence of gyphosate or glufosinate combinations with growth regulator herbicides and other agrochemicals in controlling gyphosate-resistant weeds. Weed Technology 26:638643.

DeBoer GJ, Thornburgh S, Her RJ (2006). Uptake, translocation and metabolism of the herbicide florasulam in wheat and broadleaf weeds. Pest Management Science 62(4):316-324. 
Dhima KV, Eleftherohorinos IG (2001). Influence of nitrogen on competition between winter cereals and sterile oat. Weed Science 49:7782.

Fahad S, Hussain S, Chauhan BS, Saud S, Wu C, Hassan S, ... Huang J (2015). Weed growth and crop yield loss in wheat as influenced by row spacing and weed emergence times. Crop Protection 71:101-108.

FAO (2014). FAOSTAT database. Food and Agriculture Organization of the United Nations. Retrieved April 10, 2016 from www.fao.org/faostat/.

Gomes C, Costa R, Almeida AS, Coutinho J, Pinheiro N, Coco J, ... Maçãs B (2016). Septoria leaf blotch and yellow rust control by: fungicide application opportunity and genetic response of bread wheat varieties. Emirates Journal of Food and Agriculture 28:493-500.

Gooding MJ, Dimmock JPRE, France J, Jones SA (2000). Green leaf area decline of wheat flagleaves: The influence of fungicides and relationships with mean grain weight and grain yield. Annals of Applied Biology 136:77-84.

Gut M, Bichoński A (2007). Technological quality and yield's components of winter wheat lines under Polish climatic conditions. Cereal Research Communications 35:151-161.

Holtz MD, Kumar K, Zantinge JL, Xi K (2014). Genetic diversity of Puccinia striiformis from cereals in Alberta, Canada. Plant Pathology 63:415-424.

Ishikawa S, Hare MC, Kettlewell PS (2012). Effects of strobilurin fungicide programmes and fertilizer nitrogen rates on winter wheat: Severity of Septoria tritici, leaf senescence and yield. The Journal of Agricultural Science 150:411-426.

ISO 21415-1 (2006). Wheat and wheat flour-Gluten content-Part 1: Determination of wet gluten by a manual method.

Jordan DL, Lancaster SH, Lanier JE, Lassiter BR, Johnson PD (2009). Weed management in peanut with herbicide combinations containing imazapic and other pesticides. Weed Technology 23:6-10.

Karkanis A, Travlos IS, Bilalis DJ, Tabaxi EI (2016). Integrated weed management in winter cereals in Southern Europe. In: Travlos IS, Bilalis DJ, Chachalis D (Eds). Weed and pest control: Molecular biology, practices and environmental impact. Nova Science Publishers, Inc. USA pp 1-15.

Lancaster SH, Beam JB, Lanier JE, Jordan DL, Johnson PD (2007). Compatibility of diclosulam with postemergence herbicides and fungicides. Weed Technology 21:869-872.

Lancaster SH, Jordan DL, Johnson PW (2008). Influence of graminicide formulation on compatibility with other pesticides. Weed Technology 22:580-583.

Lopez JA, Rojas K, Swart J (2015). The economics of foliar fungicide applications in winter wheat in Northeast Texas. Crop Protection 67:35-42.

Martini LFD, Burgos NR, Noldin JA, de Avila LA, Salas RA (2015). Absorption, translocation and metabolism of bispyribac-sodium on rice seedlings under cold stress. Pest Management Science 71:1021-1029.

Qasem JR (2007). Chemical control of wild-oat (Avena sterilis L.) and other weeds in wheat (Triticum durum Desf.) in Jordan. Crop Protection 26:1315-1324.

Robinson MA, Cowbrough MJ, Sikkema PH, Tardif FJ (2013). Winter wheat (Triticum aestivum L.) tolerance to mixtures of herbicides and fungicides applied at different timings. Canadian Journal of Plant Science 93:491-501.

Sarwar M (2015). Commercial insecticide formulations and their applications in the field. International Journal Materials Chemistry Physics 1:116-123.

Terefe TG, Visser B, Pretorius ZA (2016). Variation in Puccinia graminis $\mathrm{f}$. sp. tritici detected on wheat and triticale in South Africa from 2009 to 2013. Crop Protection 86:9-16.

Uchimura Y, Sato H, Ogata T, Matsue Y (2004). Difference in the deterioration of flour quality by rainfall during ripening period in wheat. Japanese Journal CropScience 73:29-34.

Wiersma JJ, Motteberg CD (2005). Evaluation of five fungicide application timings for control of leaf-spot diseases and fusarium head blight in hard red spring wheat. Canadian Journal of Plant Pathology 27:25-37. 